\title{
PHENOLOGY OF Calotropis procera (Ait.) W.T. Aiton ACCESSIONS BASED ON MORPHOPHYSIOLOGICAL CHARACTERISTICS ${ }^{1}$
}

\author{
ISAIAS VITORINO BATISTA DE ALMEIDA ${ }^{2 *}$, MAÍLSON MONTEIRO DO RÊGO ${ }^{3}$, FABIANE RABELO DA \\ COSTA BATISTA ${ }^{4}$, ELIZANILDA RAMALHO DO REGO ${ }^{3}$, RISELANE DE LUCENA ALCÂNTARA BRUNO ${ }^{5}$
}

\begin{abstract}
The objective of this work was to evaluate the phenology of Calotropis procera accessions based on morphophysiological characteristics. Seeds of 70 C. procera accessions were collected between October 2015 and January 2016 in areas where the species naturally occurs in Northeastern Brazil. These accessions make up the current germplasm collection of the National Institute of the Semi-arid (INSA). The experiment was conducted in a greenhouse at INSA, in Campina Grande - PB, from January to September in 2016. The plants were cultivated in plastic pots filled with soil. Fertilization was conducted according to soil analysis recommendations and plants were irrigated at a 3-day interval. Morphophysiological characteristics were recorded 30 days after sowing (DAS) and 30-day intercalated evaluations were conducted up to 240 DAS. In addition, physiological indexes were estimated and leaf fall, flowering, and fruiting were evaluated at 120 DAS. Mean of each characteristic was obtained using the adjustment and the selection of regression models to explain the growth of $C$. procera based on the coefficient of determination. The vegetative stage of $C$. procera occurs during the $240 \mathrm{DAS}$, with continuous fall and production of leaves, while the reproductive stage begins at 153 DAS, continuing until 222 DAS, depending on the accession, making emission of inflorescences constant on plants after the beginning of flowering. The physiological indexes are efficient to estimate the growth of $C$. procera accessions.
\end{abstract}

Keywords: Silk blossom. Reproductive system. Vegetative growth.

\section{FENOLOGIA DE ACESSOS DE Calotropis procera (Ait.) W.T. Aiton COM BASE EM CARACTERÍSTICAS MORFOFISIOLÓGICAS}

\begin{abstract}
RESUMO - Objetivou-se com esta pesquisa avaliar a fenologia de acessos de C. procera com base em características morfofisiológicas. Foram coletadas sementes de 70 acessos de C. procera entre outubro de 2015 e janeiro de 2016, em áreas de ocorrência natural da espécie, na região Nordeste do Brasil. Atualmente esses acessos compõem a coleção de germoplasma do Instituto Nacional do Semiárido (INSA). O experimento foi conduzido em casa de vegetação no INSA, em Campina Grande - PB, entre janeiro e setembro de 2016.

As plantas foram cultivadas em vasos plásticos preenchidos com solo, onde foi feita a adubação conforme recomendação de análise do solo e foram irrigadas em intervalos de 3 dias. Realizaram-se leituras de características morfofisiológicas, inicialmente aos 30 dias após a semeadura (DAS) com avaliações intercaladas em 30 dias até os 240 DAS. Além disso, estimaram-se os índices fisiológicos até os 120 DAS e avaliaram-se a queda de folhas, a floração e a frutificação. Obteve-se a média de cada característica com o ajuste e seleção dos modelos de regressão para explicar o crescimento de C. procera, com base no coeficiente de determinação. $\mathrm{O}$ estádio vegetativo de $C$. procera ocorre durante os 240 DAS, com queda e produção de folhas continuamente, enquanto que o estádio reprodutivo se inicia aos 153 DAS, prosseguindo até os 222 DAS, dependendo do acesso, tornando-se constante a emissão de inflorescência nas plantas após o início da floração. Os índices fisiológicos são eficientes para estimar o crescimento de acessos de C. procera.
\end{abstract}

Palavras-chave: Flor-de-seda. Sistema reprodutivo. Crescimento vegetativo.

\footnotetext{
${ }^{*}$ Corresponding author

${ }^{1}$ Received for publication in $12 / 13 / 2017$; accepted in $01 / 29 / 2019$.

Paper extracted from the doctoral thesis of the first author.

${ }^{2}$ Experimental Station Pendência, Empresa Paraibana de Pesquisa, Extensão Rural e Regularização Fundiária, Soledade, PB, Brazil; isaiasvba@gmail.com - ORCID: 0000-0003-1070-6536.

${ }^{3}$ Center for Agricultural Sciences, Universidade Federal da Paraíba, Areia, PB, Brazil; mailson@cca.ufpb.br - ORCID: 0000-0003-30966992, elizanilda@cca.ufpb.br - ORCID: 0000-0001-7376-7569.

${ }^{4}$ Biotechnology laboratory, Instituto Nacional do Semiárido, Campina Grande, PB, Brazil; fabiane.costa@insa.gov.br - ORCID: 0000-0003 -3868-1131.

${ }^{5}$ Department of Phytotechny and Environmental Sciences, Universidade Federal da Paraíba, Areia, PB, Brazil; lanebruno.bruno@gmail.com - ORCID: 0000-0002-4206-6417.
} 


\section{INTRODUCTION}

Calotropis procera [Ait.] W.T. Aiton (Apocynaceae) grows in arid and semi-arid climates and is native to Africa, Madagascar, the Arabian Peninsula, Southwest Asia, India, China, and Malaysia. This plant species is used for medicinal purposes and cheese production and has phytoremediation and allelopathic potential for the production of bioenergy and biofuels (HASSAN et al., 2015). In addition, previous studies have investigated $C$. procera because of the potential for this species to invade degraded areas (ISMAIL, 1992; SOBRINHO et al., 2013; FARAHAT et al., 2015; ALMEIDA et al., 2018).

In Brazil, researchers have examined the forage potential of C. procera because of its dry matter productivity, biomass production, and chemical composition, and have recommended its inclusion in animal diets Costa et al. (2009). However, further studies are needed regarding the production of $C$. procera.

Primary production of $C$. procera crops has been examined in previous phenology studies. Phenology can be used to evaluate patterns of plant growth and development (ZHANG et al., 2006). Growth analysis has also been used to explain differences in growth, either genetic or due to changes in the environment (PEIXOTO; PEIXOTO, 2009), thereby improving our understanding of plant productivity. Studies have evaluated the phenology of $C$. procera in environments with a natural occurrence, that is, in urban areas of Cairo, Egypt (FARAHAT et al., 2015) and Caatinga (Brazilian Dry Forests) areas in Serra Talhada, Brazil (SOBRINHO, et al., 2013) and found that flowering and fruiting are continuous throughout the year.
They analyzed the phenology through the cultivation, using the estimation of physiological indexes (ISMAIL, 1992), besides the evaluation of the regrowth of the species (ANDRADE, et al., 2005). The initial growth of $C$. procera has been studied as a function of water stress (FROSI et al., 2013), of different substrates (OLIVEIRA et al., 2009) and evaluation of different genotypes (ALMEIDA et al., 2017a), contributing to the domestication and cultivation of the species.

However, there are no studies characterizing the growth of $C$. procera populations from different regions of the Brazilian Northeast from seed cultivation; therefore, studies are necessary for this sense, since the characterization of the growth of a plant species is a fundamental step for understanding the dynamics of the culture, which helps to carry out further works in the breeding program. Thus, the objective of this study was to evaluate phenology of $C$. procera accessions based on morphophysiological characteristics.

\section{MATERIAL AND METHODS}

Seeds of 70 C. procera accessions were collected from October 2015 to January 2016 in Northeastern Brazil, where this species naturally occurs (Figure 1). Currently, these accessions comprised make up the collection of germplasm of the Instituto Nacional do Semiárido (INSA) (National Institute of the Semiarid). The experiment was conducted in a greenhouse at INSA in Campina Grande, Paraíba $\left(7^{\circ} 16^{\prime} 23.25^{\prime \prime} \mathrm{S}, 35^{\circ} 58^{\prime} 17.06^{\prime \prime} \mathrm{W}\right.$, $531 \mathrm{~m}$ above sea level), from January to September 2016.

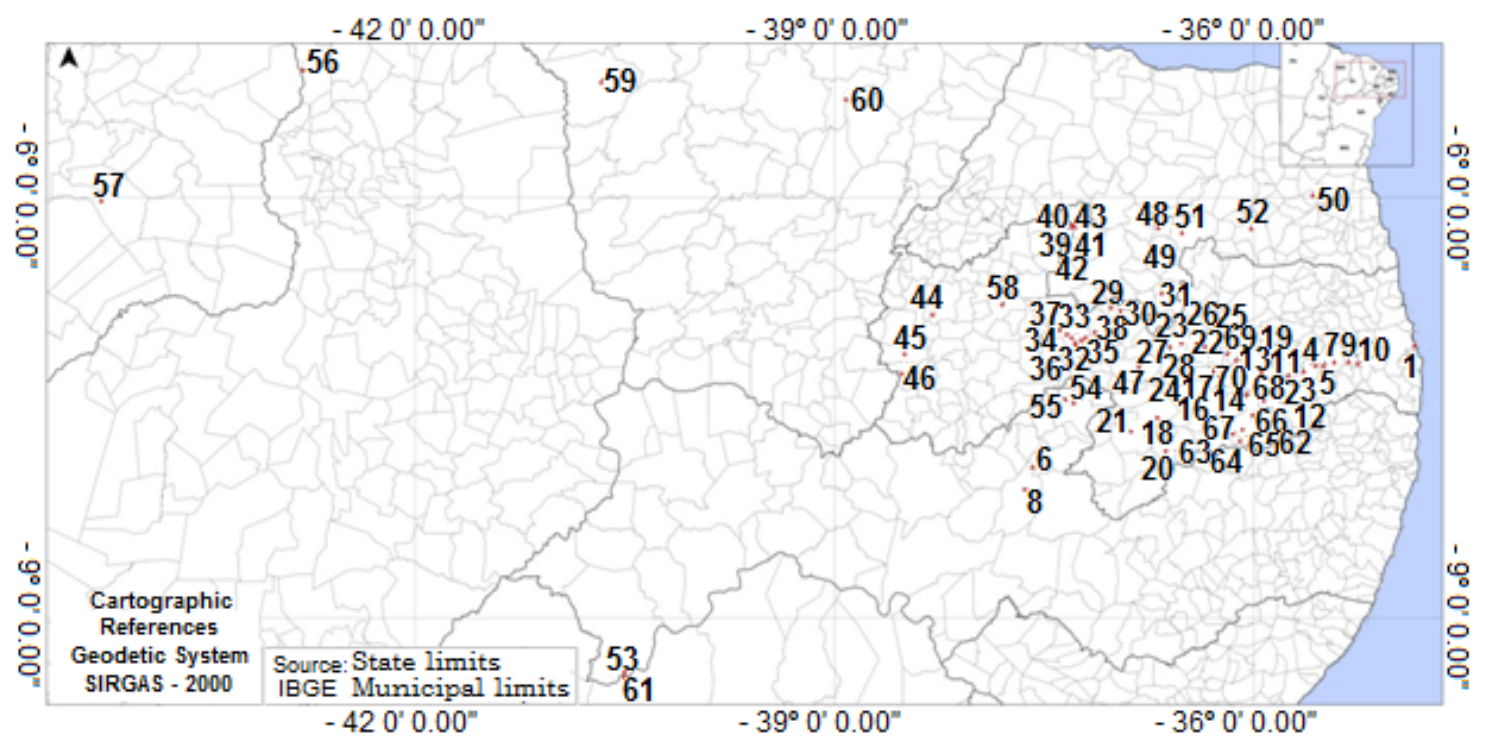

Figure 1. Collection locations for seeds from 70 Calotropis procera accessions in Northeastern Brazil. 
Physiologically mature fruit with open capsules and brown colored seeds were collected. Seeds were hand-extracted and placed to dry in the shade. After drying, the seeds were stored in paper bags at room temperature until sowing. Then, $20 \mathrm{C}$. procera seeds were sown per pot. Plants were thinned after the emergency evaluation, leaving only five seedlings in each pot. Plants were then collected and weighed at different time points over the experiment, with only one plant remaining 240 days after sowing (DAS).

The plants were cultivated in $10 \mathrm{~L}$ plastic pots with the following dimensions: $25 \mathrm{~cm}$ height, $27 \mathrm{~cm}$ opening, and $18 \mathrm{~cm}$ diameter base. At the base of the pots, a drainage system with four holes was installed to facilitate water flow. The pots were filled with sandy soil with the following chemical composition: $\mathrm{pH} \quad 4.9 ; 2.55 \mathrm{mg} / \mathrm{dm}^{3} \mathrm{P} ; 71.6 \mathrm{mg} / \mathrm{dm}^{3} \mathrm{~K}^{+}$; $0.09 \mathrm{cmolc} / \mathrm{dm}^{3} \mathrm{Na}^{+} ; 1.82 \mathrm{cmolc} / \mathrm{dm}^{3} \mathrm{H}^{+}+\mathrm{Al}^{+3}$; $0.4 \mathrm{cmolc} / \mathrm{dm}^{3} \quad \mathrm{Al}^{+3} ; \quad 0.34 \quad \mathrm{cmolc} / \mathrm{dm}^{3} \quad \mathrm{Ca}^{+2}$;
$0.8 \mathrm{cmolc} / \mathrm{dm}^{3} \quad \mathrm{Mg}^{+2} ; \quad 1.41 \mathrm{cmolc} / \mathrm{dm}^{3} \quad$ sum exchangeable bases; $3.22 \mathrm{cmolc} / \mathrm{dm}^{3}$ cation exchange capacity, and $1.79 \mathrm{~g} / \mathrm{kg}$ organic matter. The soil physical composition was $900 \mathrm{~g} / \mathrm{kg}$ sand $(2-0.05 \mathrm{~mm}), 60 \mathrm{~g} / \mathrm{kg}$ silt $(0.05-0.002 \mathrm{~mm}), 40 \mathrm{~g} / \mathrm{kg}$ clay $(<0.002 \mathrm{~mm})$, and sand according to its textural class.

Soil was fertilized according to the chemical and physical analysis recommendations, with $8 \mathrm{~g}$ of single super phosphate applied at foundation and $10 \mathrm{~g}$ of potassium chloride and $10 \mathrm{~g}$ of urea applied at 30 and 90 days after sowing (DAS). Plants were irrigated every 3 days, based on water potential and soil field capacity. A Deltamethrin-based product $(25 \mathrm{~g} / \mathrm{L})$ was applied to control aphids (Aphis nerii).

The relative air humidity (\%) and maximum, minimum, and average temperature $\left({ }^{\circ} \mathrm{C}\right)$ obtained inside the greenhouse during the experiment are shown in Figure 2.

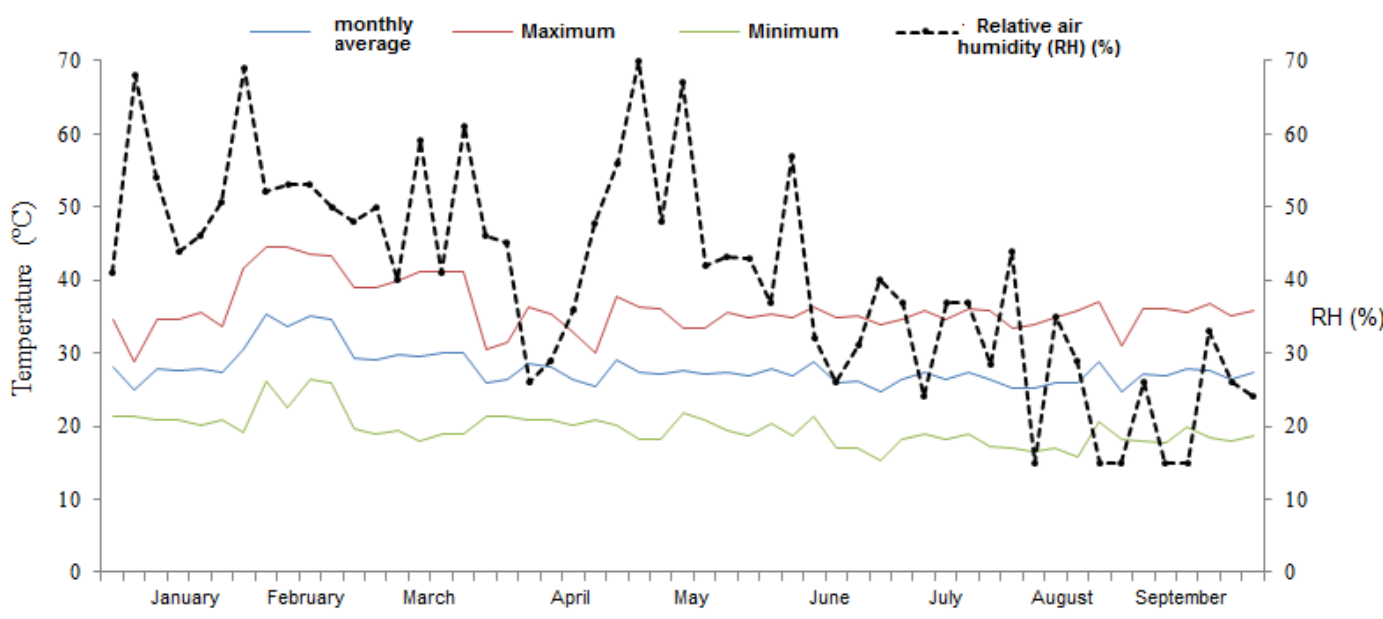

Figure 2. Relative air humidity $(\%)$ and monthly average, maximum, and minimum temperature $\left({ }^{\circ} \mathrm{C}\right)$ inside the greenhouse during the experiment.

The following characteristics were evaluated: seedling emergence (SE), emergence speed rate (ESR), first count (FC), and seedling vigor index (SVI) by counting the number of seedlings that emerged between the sixth and the tenth day after sowing (ALMEIDA et al., 2017b). Plant height (HEIGHT), stem diameter (SD), number of leaves (NL), average leaf length (ALL), average leaf width (ALW), leaf area (LA), and total leaf area (TLA) were obtained at 30,60,90,120,150,180, 210, and 240 DAS. Total dry mass (TDM) was also measured at $30,60,90$, and 120 DAS by analytically weighing $(\mathrm{e}=0.0001 \mathrm{~g})$ after drying in a forced circulation air oven at $65^{\circ} \mathrm{C}$ until constant mass was reached. In addition, leaf fall, flowering, and fruiting were evaluated daily.

Plant height $(\mathrm{cm})$ was determined by measuring the distance from the lap to apical bud using a ruler. A digital caliper was used to measure SD (mm) at the base of the stem, corresponding to the lap of the plants. Only fully expanded leaves were counted for NL, and lengths (cm) and widths (cm) were measured for three leaves from the lower, middle and upper section of the plant to obtain ALL and ALW. Individual leaf area was obtained using the equation LA $\left(\mathrm{cm}^{2}\right)=\mathrm{W} \times \mathrm{L} \times 0.75$, proposed by Moreira Filho et al. (2007) for C. procera. TLA is the sum of all LA measurements for each leaf.

Chlorophyll A and B fluorescence were measured at the apex leaves (CLA and CLB) at 30, $60,90,120,150,180,210$, and 240 DAS using Clorofilog Falker CFL 1030. The following physiological indexes were also estimated every 30 days up to 120 DAS using formulas provided in Hunt (1982) and Benincasa (2004): absolute growth rate (AGR), relative growth rate (RGR), net assimilation rate (NAR), leaf area ratio (LAR), and specific leaf area (SLA).

This study used a randomized block experimental design with 70 accessions in three replications and a total of 210 plots. The mean of each variable was obtained by adjusting and selecting regression models to explain the growth of C. procera based on the coefficient of determination 
using Table Curve 2D software (SYSTAT, 2002).

\section{RESULTS AND DISCUSSION}

Seedling emergence (SE) of $C$. procera started at 6 DAS and stabilized at 10 DAS, with initial SE ranging from 5 to $100 \%$ (mean: $55 \%$ ). For final SE, mean values ranged from $15 \%$ to $100 \%$, with an overall mean of $92.92 \%$. Emergence speed rate (ESR) ranged from 2.46 to 20 , with an overall mean of 14.73. Seedling vigor index (SVI) ranged from 0.12 to 2 , with an overall mean of 0.37 . These values are relatively high, as these seeds are from plants with occurrence natural that have a natural variability for the expression of these characteristics (ALMEIDA et al., 2017b; ALMEIDA et al., 2018).

Germination and emergence of $C$. procera seeds have been studied, with promising results (OLIVEIRA-BENTO et al., 2013; OLIVEIRABENTO et al., 2015; ALMEIDA et al., 2017b; ALMEIDA et al., 2018), with no finding of dormancy and values that are also relatively high in the present study. These results show that $C$. procera has the potential to be cultivated as a xerophytic crop by using seeds directly in the production area as emergence percentage, vigor of seedlings, and pivotal root formation are essential characteristics for the establishment of seedlings in semi-arid regions of Brazil (ALMEIDA et al., 2017b; ALMEIDA et al., 2018).

Continuous production of $C$. procera leaves was observed during the entire experiment (240 DAS) (Figure 3), corroborating the results of Lottermoser (2011) and Farahat et al. (2015). This indicates that growth occurs throughout the year and that it is a perennial shrub. The drop of cotyledon leaves was counted, which began at 23 DAS and lasted until 48 DAS. Then, the drop of the first pair of fully expanded leaves located in the lower part of the plants was observed, beginning at 40 DAS and lasting until 57 DAS. The second pair of leaves in the lower section of the plants began to fall abruptly at 70 DAS, persisting until 86 DAS. At 94 DAS, a marked drop of the third pair of leaves was observed, continuing until 113 DAS. The abscission of the fourth pair of leaves from the base started at 133 DAS and continued until 152 DAS. However, from this evaluation period, a sharp fall in the lower and middle sections of the plants was noted; this was related to a phase change, which preceded the beginning of flowering of some accessions.
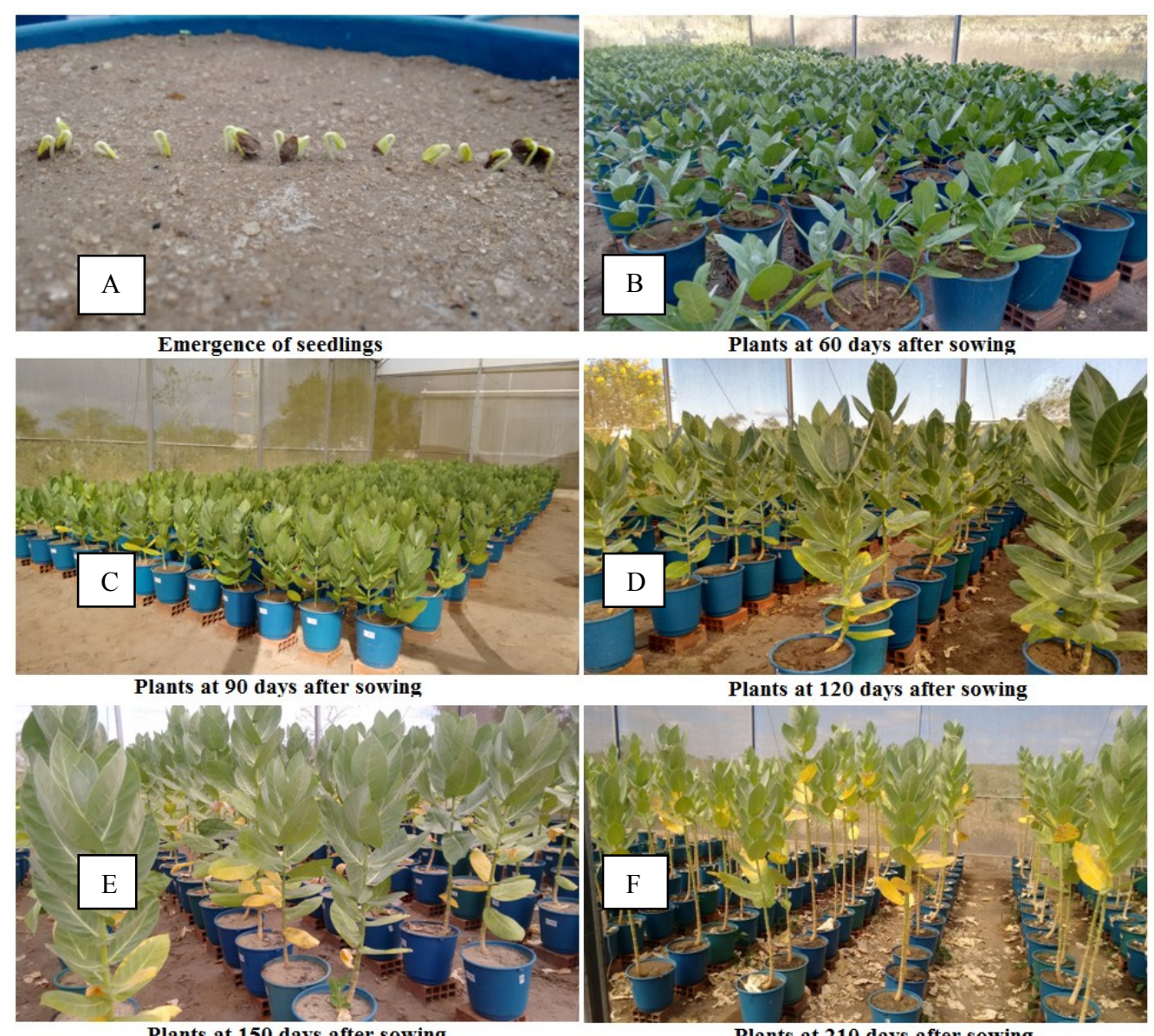

Plants at 150 days after sowing

Plants at 210 days after sowing

Figure 3. Vegetative stages of Calotropis procera accessions, grown in a greenhouse at Instituto Nacional do Semiárido (INSA). A) Seedling emergence; B) plants at 60 days after sowing; C) plants at 90 days after sowing; D) plants at 120 days after sowing; E) plants at 150 days after sowing; F) plants at 210 days after sowing.

Rev. Caatinga, Mossoró, v. 32, n. 2, p. 543 - 551, abr. - jun., 2019 
The observed leaf fall is typical of $C$. procera, a perennial plant, because senescent leaves, which are usually at the base of the plant, are continually replaced by new leaves at the apex. Kissmann and Groth (1992) found that leaves are more abundant in the upper part of the plant because lower leaves gradually become detached. Francis (2004) reported that when the plant matures, it has relatively few leaves at its apex. The replacement of dry leaves by new leaves is a critical characteristic of this species and is useful for livestock in semi-arid regions, as it supplies natural hay for feeding animals in dry seasons (COSTA et al., 2009; ALMEIDA et al., 2018).

The reproductive stage occurred at 153 DAS

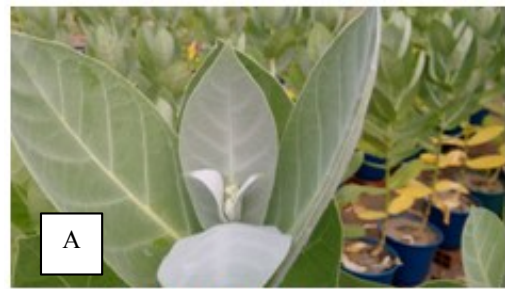

Flowering onset

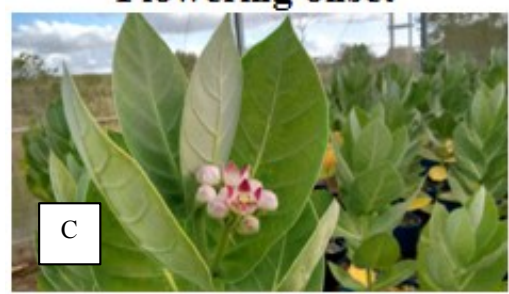

Anthesis

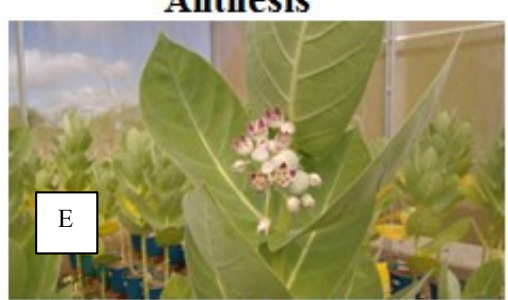

Fruit formation (accession 20) and continued to 222 DAS, depending on the access. Emission of inflorescence was constant in the plants after flowering began (Figure 4). This observation corroborates results published by Sobrinho et al. (2013) and Farahat et al. (2015), which showed flowering and continuous fruiting over the year in $C$. procera plants in Caatinga areas and in urban areas in the city of Cairo in Egypt, respectively. In contrast, Ismail (1992) observed that the beginning of flowering in $C$. procera plants occurred at 15 months after emergence (approximately 450 days), possibly because of differences in the genetic material or even in function of the climatic conditions during the experiment.

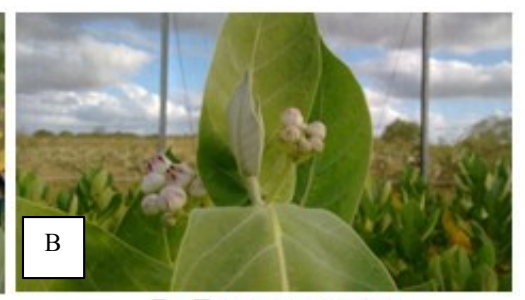

Inflorescences

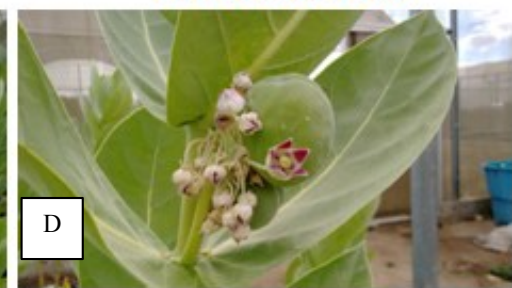

Abortion Floral Buds

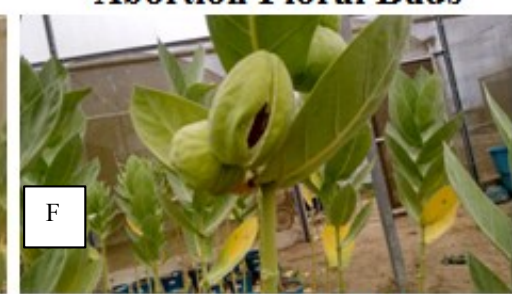

Fruit Maturation

Figure 4. Reproduction stages of Calotropis procera accessions grown in a greenhouse at Instituto Nacional do Semiárido (INSA). A) Flowering onset; B) Inflorescences; C) Anthesis; D) Abortion Floral Buds; E) Fruit formation; F) Fruit Maturation.

In this study, several accessions presented late flowering (beginning between 190 and 222 DAS), occurring 37 to 69 days after the beginning of flowering of the first accession. An absence of flowering was observed in some accessions, likely due to genetics, as flowering only occurred in plants taller than $1.10 \mathrm{~m}$.

The total number of flower buds per inflorescence ranged from 11 to 24, with an overall average of 19 buttons. Inflorescence emission occurred at the apex of the plant, with subsequent emission of new leaves, followed by emission of new inflorescence and continuous growth at plant height. The opening of the first flowers (anthesis) occurred 16 to 30 days (mean: 22 days) after inflorescence emission. Farahat et al. (2015) observed monthly variability of 4.7 to 12.4 for the number of flowers per inflorescence and 0.8 to 1.5 for the number of fruits per inflorescence.

$C$. procera is an autogamous species; thus, after anthesis, the petals close the flower and fruit formation occurs (Figure 4). Fruit formation was observed in only one or two flowers in inflorescence, representing a fertility rate ranging from $3.75 \%$ to $11.21 \%$ (mean: 6.95\%). Therefore, fertility rates were low, and a marked drop of floral bud and abortion of most flowers after anthesis was found in all accessions. These results are characteristic of many species of Asclepiadoideae (WYATT; BROYLES, 2012), which have very low fruiting 
percentages that range from 0.3 to $5 \%$. Farahat et al. (2015) found that reproductive success ranged from $5.4 \%$ to $12.8 \%$, similar to results from this study.

The onset of fruit formation occurred approximately 14 days after anthesis, ranging from 8 to 26 days. Growth and maturation phases usually persisted until 70 days after anthesis, ranging from 68 to 90 days. In contrast, ISMAIL (1992) observed fruit ripening 18 months after emergence (approximately 90 days after flowering), possibly
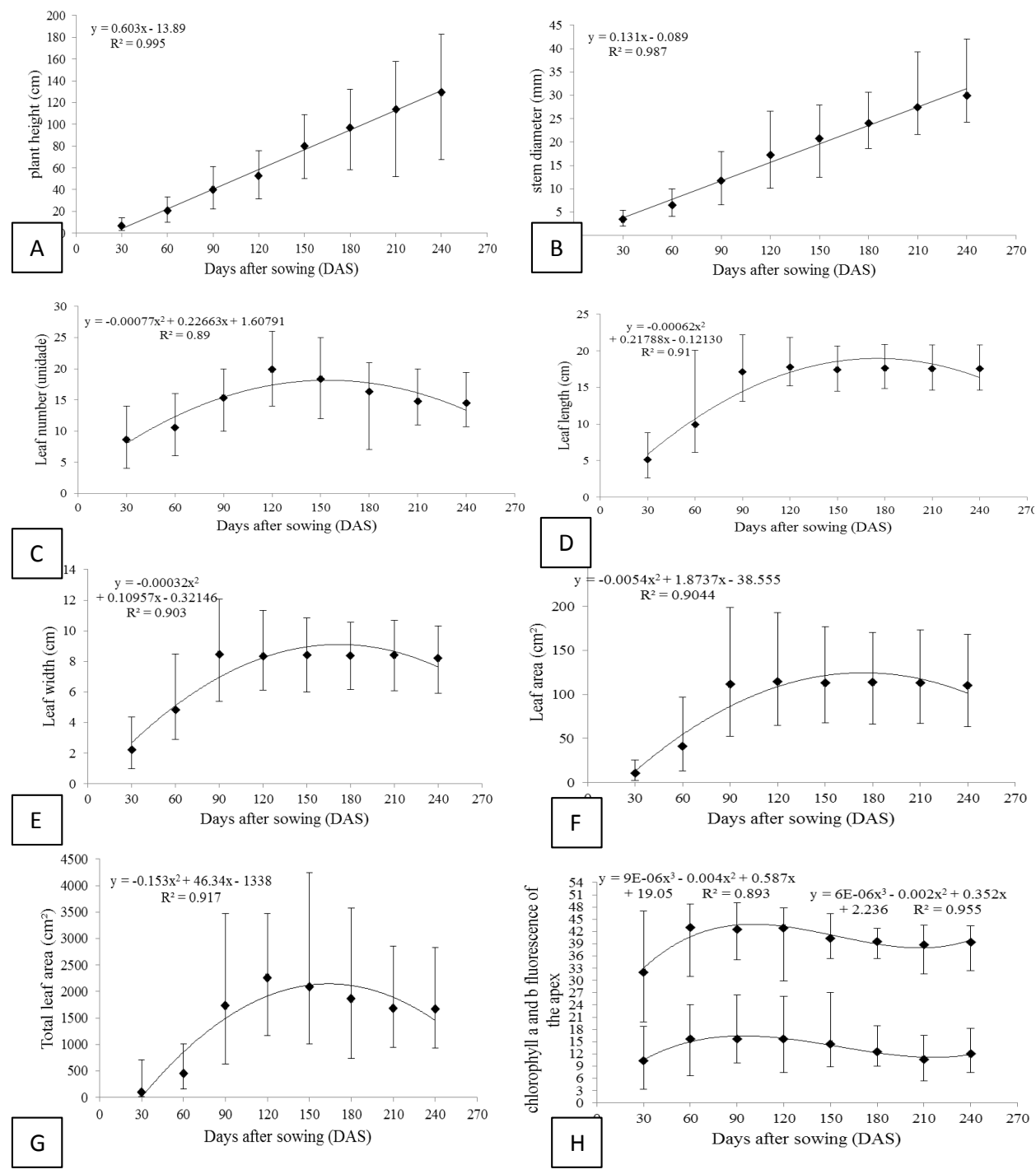

Figure 5. Regression models of the mean and variation amplitude of the following characteristics: A) plant height, B) stem diameter, C) leaf number, D) leaf length, E) leaf width, F) leaf area, G) total leaf area, and H) chlorophyll a and b fluorescence of the apex of 70 Calotropis procera accessions. X-axis shows days after sowing (DAS).

The overall mean NAR and SD of the accessions increased linearly as a function of the cultivation period (Figure $5 \mathrm{~A}$ and $5 \mathrm{~B}$ ), reaching an NAR of $129.28 \mathrm{~cm}$ and SD of $30 \mathrm{~mm}$ with increments of $1837.53 \%$ and $772 \%$, respectively. Farahat et al. (2015) observed higher height (1.46 m) and smaller height $(1.20 \mathrm{~m})$ in naturally occurring plants, in urban areas in the city of Cairo, Egypt. In this study, the tallest plant $(1.89 \mathrm{~m})$ was from accession 20 and the shortest plant $(66 \mathrm{~cm})$ was from due to differences in genetic material or climatic conditions.

Regression models were adjusted to define the standard growth curve of $C$. procera accessions and identify the optimal point of each characteristic (Figure 5). According to Barbero et al. (2013), the standard growth curve should be determined by analyzing changes in plant production as a function of time. accession 28. C. procera usually grows to a height of approximately $2 \mathrm{~m}$, but it can reach 5-6 m with a stem diameter of $25 \mathrm{~cm}$ (KISSMANN; GROTH, 1992; FRANCIS, 2004), confirming he linear growth observed in this study.

For the overall NL mean, a quadratic adjustment was observed as a function of cultivation time, with an estimated maximum value of 18 leaves per plant obtained at 147 DAS (Figure 5C). After this period, a decrease of $26.06 \%$ in NL occurred 
until 240 DAS. This indicates that despite the continuous production of leaves, the beginning of flowering contributed to a reduction in production due to the allocation of photoassimilates of leaves for formation of inflorescences, resulting in a severe leaf drop (TAIZ et al., 2017).

A quadratic response for LAL, LAW, LA, and TLA was related to the number of days after sowing, with an estimated maximum value of 9.05 $\mathrm{cm}, 19.03 \mathrm{~cm}, 136.85 \mathrm{~cm}^{2}$, and $2170.82 \mathrm{~cm}^{2}$ at 171 , 175,187 , and 151 DAS, respectively. A decrease of $10.36 \% ; 8.37 \% ; 24.40 \%$, and $29.79 \%$ was also observed until 240 DAS for DAS LAL, LAW, LA, and TLA, respectively (Figure 5D, 5E, 5F, 5G).

Francis (2004) found that the leaf length of $C$. procera ranged from 7.0 to $18.0 \mathrm{~cm}$ and leaf width ranged from 5.0 to $13.0 \mathrm{~cm}$, similar to results from this study. However, Andrade et al. (2005) found an increasing linear response for NL, SD, and TLA when evaluating the regrowth of the species under field conditions, which is different than what was observed for NL in this study.

The mean fluorescence values of CLA and CLB were adjusted in a third order polynomial equation. A maximum and a minimum value of 42.89 and 38.74 at 120 and 210 DAS were obtained for CLA and a maximum and minimum value of
15.67 and 10.69 at 90 and 210 DAS for CLB, respectively (Figure 5H). Chlorophylls are green pigments in leaves that capture sunlight and convert it to chemical energy during photosynthesis. Chlorophyll a and b stood out among chlorophyll types, as they absorb energy at different wavelengths (TAIZ et al., 2017). Fluorescence for CLA was higher than CLB in all evaluation periods. This indicates that the plants grew under sunlight because plants that grow in shade generally have increased chlorophyll b levels (TAIZ et al., 2017).

A quadratic response was observed as a function of time for TDM, reaching a maximum value of $17.16 \mathrm{~g}$ at $120 \mathrm{DAS}$ (Figure 6A). It should be noted that the accumulation of dry mass is slow until 60 DAS because, in the beginning, plants depend on reserves contained in the seed to grow. Some accessions had persistence in the seedling phase, with the cotyledonary leaf drop occurring at 48 DAS. Higher growth was observed after 60 DAS, with an increase of $848.06 \%$ until 120 DAS, when the plants had a significant number of leaves and a root system capable of absorbing nutrients. This promoted an increase in the photosynthetic activity of the plants and, therefore, a significant accumulation of mass.
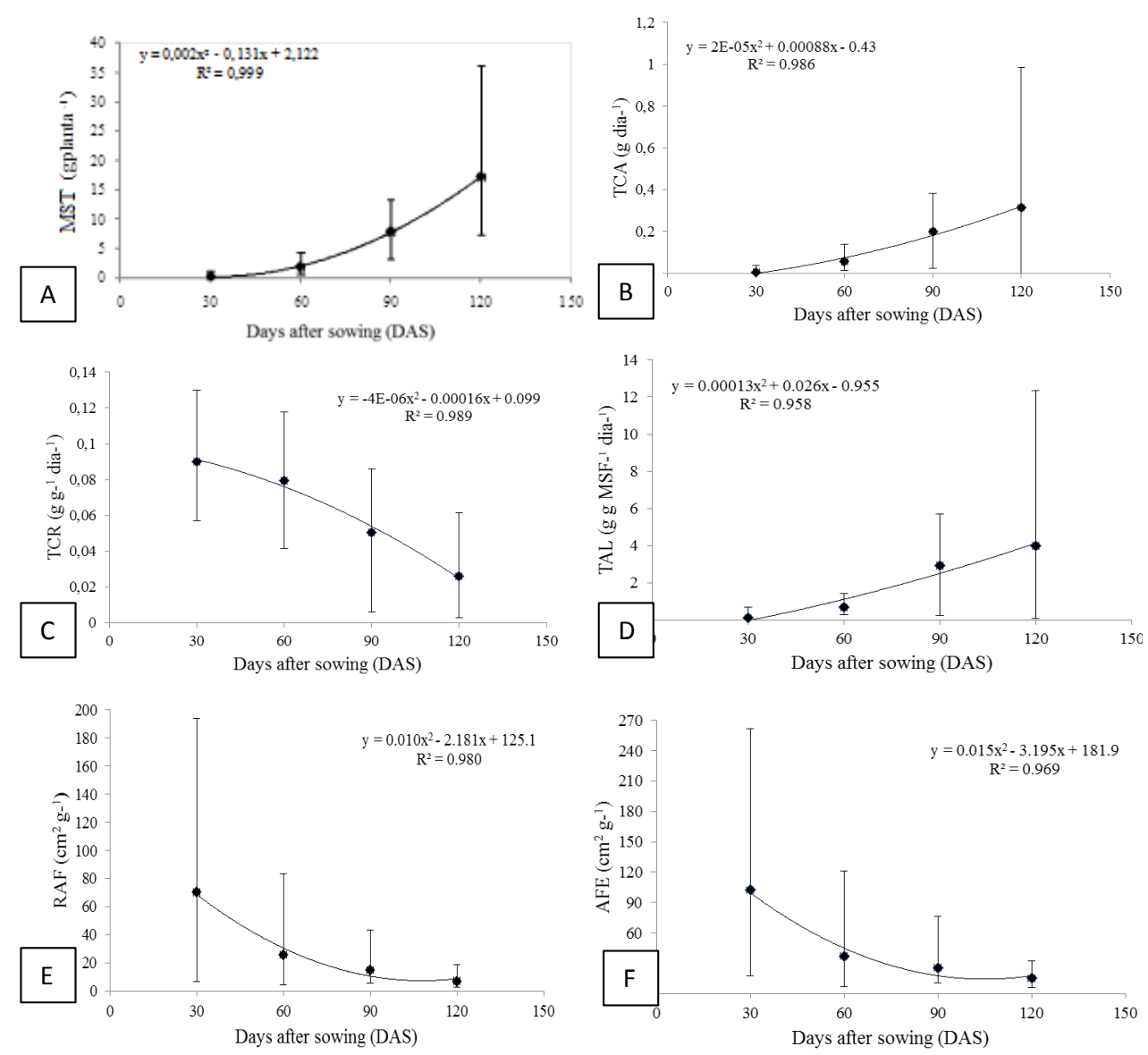

Figure 6. Regression models of means and variation amplitudes of total dry matter (TDM) (A), absolute growth rate $(A G R=)(B)$, relative growth rate $(R G W)(C)$, net assimilation rate $(N A R=)(D)$, leaf area rate $(L A R)(E)$, and specific leaf area (SLA) (F) of 70 Calotropis procera accessions across the cultivation period.

Rev. Caatinga, Mossoró, v. 32, n. 2, p. 543 - 551, abr. - jun., 2019 
The physiological indexes obtained in this study were used in the classical growth analysis described by Radford (1967), which estimated results of physiological processes involving photosynthesis, respiration, allocation, and partitioning of photoassimilates (BARBERO et al. 2013). TCA increased quadratically up to $120 \mathrm{DAS}$, with an estimated maximum growth rate of $0.313 \mathrm{~g}^{\text {day }}{ }^{-1}$ (Figure 6B).

Unlike TCA, TCR of the accessions reached maximum values at 30 DAS $\left(0.091 \mathrm{~g} \mathrm{~g}^{-1}\right.$ day $\left.^{-1}\right)$, with a decrease of $250 \%$ until 120 DAS $\left(0.026 \mathrm{~g} \mathrm{~g}^{-1}\right.$ day $\left.^{-1}\right)$ (Figure 6C). This decrease was expected, as any increase in weight, height, or leaf area over a time period is directly related to the size reached in the previous period (LIMA et al. 2007). Ismail (1992) also observed a decrease in TCR with age, with maximum values achieved during the seedling phase when the seedlings had two cotyledonary leaves and the first pair of leaves.

TAL represents the rate of increase of dry mass per unit of leaf area in the plant. Thus, it represents the efficiency of the photosynthetic apparatus of the plant in dry mass per unit leaf area per day (BARBERO et al., 2013). In this study, TAL adjustment was observed in the polynomial model, quadratic linear effect, similar to TCA. Increased TAL was observed after 60 DAS, with an increase of $494.02 \%$ until 120 DAS and a maximum value of $3.98 \mathrm{gg} \mathrm{LDM}^{-1}$ day $^{-1}$ (Figure 6D), when accessions had a higher number of leaves and higher photosynthetic activity.

The useful foliar area of a plant is represented by LAR, which corresponds to the quotient between LA (responsible for the interception of light energy and $\mathrm{CO}_{2}$ absorption) and TDM (resulting from photosynthesis). In other words, it indicates the leaf area that is being used by the plant to produce one gram of dry matter (BENINCASA, 2004). Leaf area rate can be dissociated in SLA, which corresponds to the ratio of LA to LDM (LA/LDM). In this study, as plants grew and LN, LA, TLA, and dry mass increased, there was a decline in average LAR and SLA. Thus, higher estimates of LAR $70.32 \mathrm{~cm}^{2} \mathrm{~g}^{1}$ (range: 6.46 to $194.17 \mathrm{~cm}^{2} \mathrm{~g}^{1}$ ) and SLA of 102.45 $\mathrm{cm}^{2} \mathrm{~g}^{1}$ (range: 17.59 to $261.54 \mathrm{~cm}^{2} \mathrm{~g}^{1}$ ) were reached at $30 \mathrm{DAS}$, with decreases of $871.27 \%$ and $582.54 \%$ until 120 DAS, respectively (Figure $6 \mathrm{E}$ and $6 \mathrm{~F}$ ). ISMAIL (1992) obtained a maximum value $\left(225 \mathrm{~cm}^{2}\right.$ $\left.\mathrm{g}^{-1}\right)$ two months after emergence, with a continuous decline in LAR and SLA after the seedling phase as the plant aged.

\section{CONCLUSIONS}

The vegetative stage of $C$. procera occurred during the 240 day study, with continuous production and leaf drop in addition to increased height and stem diameter. The reproductive stage of C. procera, which varied for different accessions, began at 153 DAS and continued until 222 DAS. The emission of inflorescence in the plants was constant after the beginning of flowering. Results of this study indicate that absolute growth rate (TCA), relative growth rate (TCR), net assimilation rate (TAL), leaf area ratio (RAF), and specific leaf area (AFE) are efficient ways to estimate the perennial growth of $C$. procera accessions.

\section{ACKNOWLEGMENTS}

We thank Instituto Nacional do Semiárido (INSA) for supplying the physical structure and for supporting the execution of this study.

\section{REFERENCES}

ALMEIDA, I. V. B. et al. Characterization and early selection of silk blossom (Calotropis procera) genotypes with forage potential. Revista Caatinga, v. 30, n. 3, p. 794-801, 2017a.

ALMEIDA, I. V. B. et al. Genetic diversity among Calotropis procera (Aiton) WT Aiton genotypes according to seed physiological quality. Revista Caatinga, v. 30, n. 4, p. 912-919, 2017 b.

ALMEIDA, I. V. B. et al. Genetic variability among accessions of Calotropis procera based on agronomic characters. Journal of Experimental Agriculture International, v. 25, n. 6, p. 1-12, 2018.

ANDRADE, M. V. M. et al. Fenologia da Calotropis procera Ait. R. Br., em função do sistema e da densidade de plantio. Archivos de Zootecnia, v. 54, n. 208, p. 631-634, 2005.

BARBERO, L. M. et al. Análise de crescimento em plantas forrageiras aplicada ao manejo de pastagens. Veterinária Notícias, v. 19, n. 2, p. 71-85, 2013.

BENINCASA, M. M. P. Análise de crescimento de plantas: noções básicas. Jaboticabal, SP: FUNEP, 2004. 42 p.

COSTA, R. G. et al. Perspectivas de utilização da flor-de-seda (Calotropis procera) na produção animal. Revista Caatinga, v. 22, n. 1, p. 1-9, 2009.

FARAHAT, E. A. et al. Phenology, biomass and reproductive characteristics of Calotropis procera (Aiton) WT Aiton in South Cairo, Egypt. Rendiconti Lincei, v. 27, n. 2, p. 197-204, 2015. 
FRANCIS, J. K. Wildland Shrubs of the United States and its Territories: Thamnic Descriptions: volume 1. Gen. Tech. Rep. IITF-GTR-26. San Juan, PR: U.S. Department of Agriculture, Forest Service, International Institute of Tropical Forestry, and Fort Collins, CO: U.S., 2004. Department of Agriculture, Forest Service, Rocky Mountain Research Station. $830 \mathrm{p}$.

FROSI, G. et al. Ecophysiological performance of Calotropis procera: an exotic and evergreen species in Caatinga, Brazilian semi-arid. Acta Physiologiae Plantarum, v. 35, n. 2, p. 335-344, 2013.

HASSAN, L. M. et al. The biology of Calotropis procera (Aiton) WT. Trees, v. 29, n. 2, p. 311-320, 2015.

HUNT, R. Plant Growth Curves. The Functional Approach to Plant Growth Analysis. Edward Arnold, London, 1982.

ISMAIL, A. M. A. Physiological growth analysis of the life-history of Calotropis procera (AIT.) AIT. F. Qatar University Science Journal, v. 12, s/n., p. $94-100,1992$.

KISSMANN, K. G.; GROTH, D. Plantas infestantes e nocivas. São Paulo, SP: BASF Brasileira S. A., 1992. 798 p.

LIMA, J. F. et al. Índices fisiológicos e crescimento inicial de mamoeiro (Carica papaya L.) em casa de vegetação. Ciência Agrotecnologia, v. 31, n. 5, p. 1358-1363, 2007.

LOTTERMOSER, B. G. Colonisation of the rehabilitated Mary Kathleen uranium mine site (Australia) by Calotropis procera: toxicity risk to grazing animals. Journal of Geochemical Exploration, v. 111, n. 1, p. 39-46, 2011.

MOREIRA FILHO, E. C. et al. Estimação da área foliar da flor de seda (Calotropis procera). Archivos de Zootecnia, v. 56, n. 214, p. 245-248, 2007.

OLIVEIRA-BENTO, S. R. S. et al. Armazenamento de sementes de flor-de-seda [Calotropis procera (AITON) W.T. AITON]. Revista Caatinga, v. 28, n. 1, p. 39-47, 2015.

OLIVEIRA-BENTO, S. R. S. et al. Biometria de frutos e sementes e germinação de Calotropis procera AITON (Apocynaceae). Bioscience Journal, v. 29, n. 5, p. 1194-1205, 2013

OLIVEIRA, S. H. et al. Seedling growth of the invader Calotropis procera in ironstone rupestrian field and seasonally dry forest soils. Neotropical
Biology and Conservation, v. 4, n. 2, p. 69-76, 2009 .

PEIXOTO, C. P.; PEIXOTO, M. F. S. P. Dinâmica do crescimento vegetal: princípios básicos. In: CARVAlHO, C. A. L. et al. (Eds.). Tópicos em Ciências Agrárias. Cruz das Almas, BA: Universidade Federal do Recôncavo da Bahia, 2009, v. 1 , cap. 4 , p. $39-53$.

RADFORD, P. J. Growth analysis formulae - their use and abuse. Crop Science, v. 7, n. 3, p. 171-175, 1967.

SOBRINHO, M. S. et al. Reproductive phenological pattern of Calotropis procera (Apocynaceae), an invasive species in Brazil: annual in native areas; continuous in invaded areas of caatinga. Acta Botanica Brasilica, v. 27, n. 2, p. 456-459, 2013.

SYSTAT SOFTWARE. Table Curve 2D, version 5.01. 2002.

TAIZ, L. et al. Fisiologia e Desenvolvimento Vegetal. 5. ed. Porto Alegre, RS: Artmed, 2017. $819 \mathrm{p}$.

WYATT, R.; BROYLES, S. B. Reproductive Biology of Milkweeds (Asclepias): Recent Advances. In: KAWANO, S. (Ed.). Biological approaches and evolutionary trends in plants. London: Academic press, 2012, cap. 15, p. 255-272.

ZHANG, G. et al. Phenology of Ficus racemosa in Xishuangbanna, Southwest China. Biotropica, v. 38, n. 3, p. 334-341, 2006. 